\title{
Thermal conductivity of rocks and geothermal water
}

\section{Toplotna prevodnost kamnin in geotermalne vode}

\author{
Željko Vukelić ${ }^{\prime}$ * \\ University of Ljubljana, Faculty of Natural Sciences and Engineering, \\ Aškerčeva cesta 12, 1000 Ljubljana, Slovenia \\ *zeljko.vukelic@ntf.uni-lj.si
}

\begin{abstract}
In this article, the possibilities of use of geothermal energy in relation to the geothermal gradient and aquifer yield are described. Calculations represent information on potential geothermal water reserves that are not affected by cold return water inflow from the reinjection well after a certain period of production time. The calculations apply for continuous production of geothermal water from the aquifer without significant pumping breaks.
\end{abstract}

Key words: geothermal gradient, aquifer, reinjection well

\section{Izvleček}

V članku obravnavamo možnosti izrabe geotermalne energije na temelju geotermalnega gradienta in izdatnosti vodonosnika. Izračuni predstavljajo informacijo o potencialnih zalogah geotermalne vode, ki po določenem času izkoriščanja, še ne padejo pod vpliv dotekanja hladne vode skozi reinjekcijsko vrtino. Izračuni veljajo za kontinuirano izkoriščanje vodonosnika brez daljših prekinitev črpanja geotermalne vode iz vodonosnika.

Ključne besede: geotermalni gradient, vodonosnik, reinjekcijska vrtina 


\section{Introduction}

Geothermal energy belongs among renewable energy resources. Geothermal energy finds widespread use in the heating of residential and other buildings, as well as in electrical energy production [1]. Use of geothermal energy for the heating of residential and other buildings represents $>80 \%$ of all heating energy needs in some countries (e.g. Iceland). It is very important, therefore, to have knowledge about how to use geothermal energy in an optimal manner and not disturb the balance of underground water reserves. In other words, we need to ensure the renewal of underground water reserves and eliminate the effect of aquifer cooling because of reinjection of used, colder return water.

\section{Thermal characteristics of rocks and underground waters}

The thermal characteristics of rocks and underground waters can be defined using the following equation [1-3]:

$\lambda=a \cdot c \cdot \rho$

where

$\lambda=$ thermal conductivity (in $\mathrm{W} / \mathrm{m} \cdot \mathrm{K}$ );

$c=$ specific heat (in $\mathrm{J} / \mathrm{kg} \cdot \mathrm{K})$;

$a=$ temperature conductivity (in $\mathrm{m}^{2} / \mathrm{s}$ );

$\rho=$ density $\left(\right.$ in $\left.\mathrm{kg} / \mathrm{m}^{3}\right)$.

The thermal characteristics are not directly dependent on temperature, as with a variance of temperature, physicochemical changes occur and thus initiate the change of thermal characteristics.

\section{Thermal conductivity $\lambda$}

Thermal conductivity is the transition of heat from warmer heat sources to cooler ones. In hydrothermal deposits, heat transition occurs through convection in fluids (physical heat transfer in fluids) and conduction in rocks (physical heat transfer in solid substances, e.g. because of radiation).

Thermal conductivity is determined experimentally in laboratories and in the field, but it can be calculated too, as follows:
$\lambda=\frac{E \cdot h}{A \cdot\left(T_{2}-T_{1}\right) \cdot \tau}$

where

$E=$ amount of heat passing through a particular area $A$ (in J);

$H=$ strata thickness (in $\mathrm{m}$ );

$A=$ particular area through which the heat flux is passing $\left(\right.$ in $^{2}$ );

$T_{2}-T_{1}=$ temperature difference between strata borders (in $\mathrm{K}$ );

$\tau=$ heat flux passing time (in s).

For North-East (NE) Slovenia, we can write down the thermal conductivity in terms of rock density:

$\lambda=0.142 \times \rho^{2.86}$

\section{Specific heat c}

Specific heat is a physical quantity that describes the thermal property of the substance and defines how much energy is needed to increase the temperature of $1 \mathrm{~kg}$ mass for $1 \mathrm{~K}$, at constant pressure. For the rocks, the average value is $c_{m}=835( \pm 15 \%) \mathrm{J} / \mathrm{kg} \cdot \mathrm{K}$; and for water, the value is $c_{w}=4187 \mathrm{~J} / \mathrm{kg} \mathrm{K}$.

The calculation of specific heat of the rock in terms of porosity and at water density $1000 \mathrm{~kg} / \mathrm{m}^{3}$ and average rock density $2720 \mathrm{~kg} / \mathrm{m}^{3}$ is done as follows:

$c_{k}=\Phi \cdot c_{w} \cdot \frac{1}{g}+(1-\Phi) \cdot c_{m} \cdot \frac{2.72}{g}$

where

$\Phi=$ porosity.

Specific heat of the rocks in NE Slovenia is $c_{k}=0.602 \cdot \mathrm{e}^{-1.177 \cdot \mathrm{H}}+0.898$.

\section{Volume-specific heat capacity (co)}

This parameter describes a product of specific heat and density and is defined as the amount of energy needed to raise the temperature of $1 \mathrm{~m}^{3}$ of substance by $1 \mathrm{~K}$ at constant pressure.

$(c \rho)_{L}=(c \rho)_{f} \cdot \Phi+(c \rho)_{m} \cdot(1-\Phi)\left(\right.$ in $\left.\mathrm{J} / \mathrm{m}^{3} \cdot \mathrm{K}\right)$

Volume-specific heat capacity is a direct parameter used for the assessment and calculation of 
Measurements of the water temperature $\left({ }^{\circ} \mathrm{C}\right)$ in the well L-1/86 Mostec - Catež

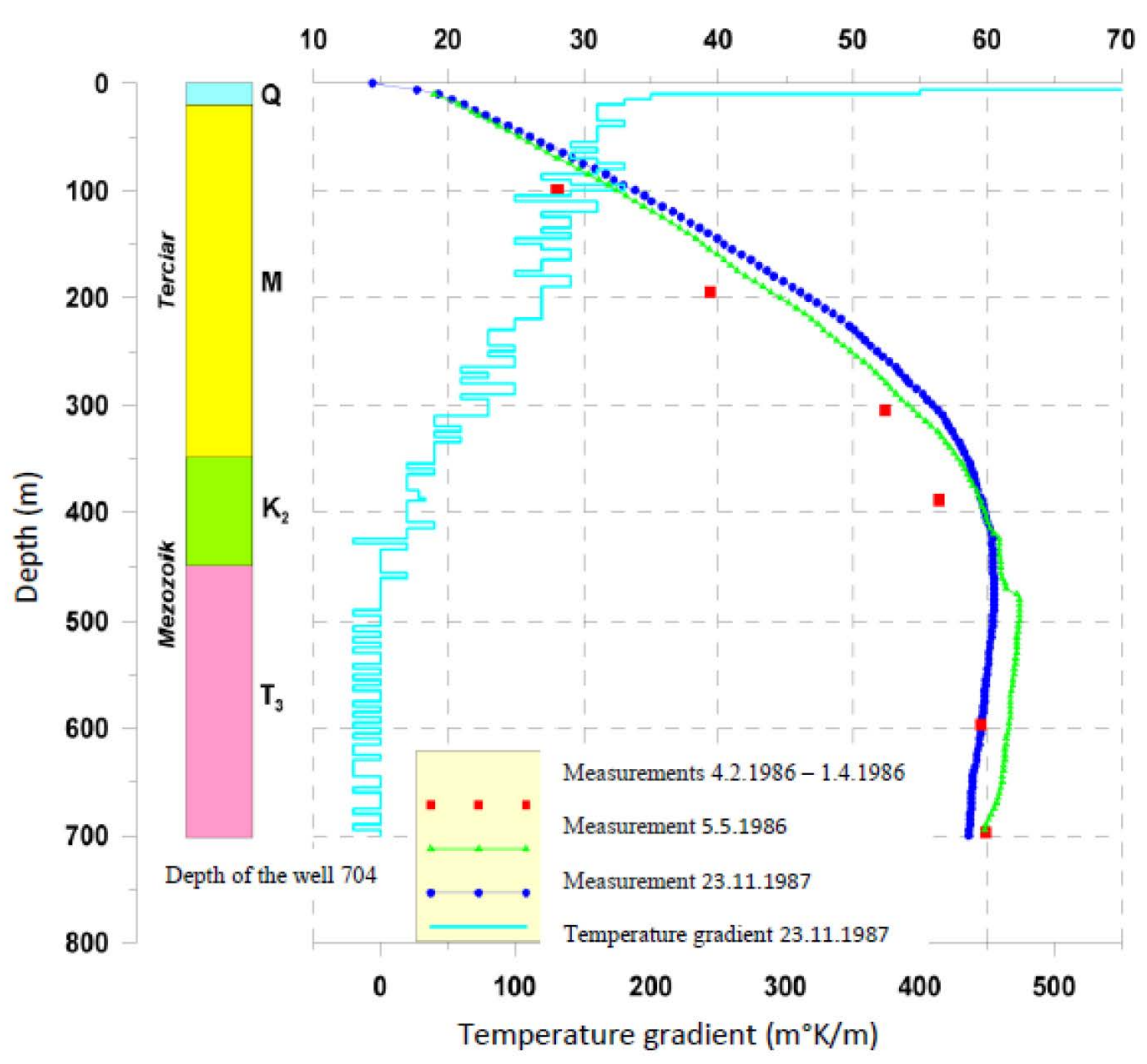

Figure 1: Field determination of temperature gradient.

geothermal energy reserves. In hydrothermal deposits, the rocks are saturated with water; thus, the following relation is derived:

$$
(c \rho)_{L}=(c \rho)_{w} \cdot \Phi+(c \rho)_{m} \cdot(1-\Phi)\left(\text { in } \mathrm{J} / \mathrm{m}^{3} \cdot \mathrm{K}\right)
$$

Volume-specific heat capacity $(c \rho)_{w}$ is affected by the water density (dependent on mineralization and ranging between 1000 and $1400 \mathrm{~kg} / \mathrm{m}^{3}$ ) and temperature. The range of the term " $(\mathrm{c} \rho)_{m}$ " depends on rock density.

\section{Temperature conductivity or diffusivity (a)}

Diffusivity is characterized by the rate of temperature equalization under nonstationary heat conduction and is represented as follows:

$a=\frac{\lambda}{c \rho} \cdot\left(\right.$ in $\left.^{2} / \mathrm{s}\right)$

\section{Geothermal gradient ( $G$ )}

The temperature at the Earth's surface depends mostly on the radiation of the sun. On average, the temperature from a depth of $30 \mathrm{~m}$ is independent of the sun's radiation. The mean value of the geothermal gradient for Europe is $0.03{ }^{\circ} \mathrm{C} / \mathrm{m}$, but in Slovenia, the newest research results show the value of geothermal gradient as approximately $0.06^{\circ} \mathrm{C} / \mathrm{m}$.

$G_{t}=\frac{T-T_{0}}{H}=\frac{q}{\lambda}$

where

$T=$ temperature measured at specific depth (K);

$T_{0}=$ average mean ground temperature for NE Slovenia $\left(11.6^{\circ} \mathrm{C}\right)$;

$H=$ depth of temperature measurement (m).

The geothermal gradient is directly proportional to the heat flux but inversely proportional to heat conduction, which changes with depth as 


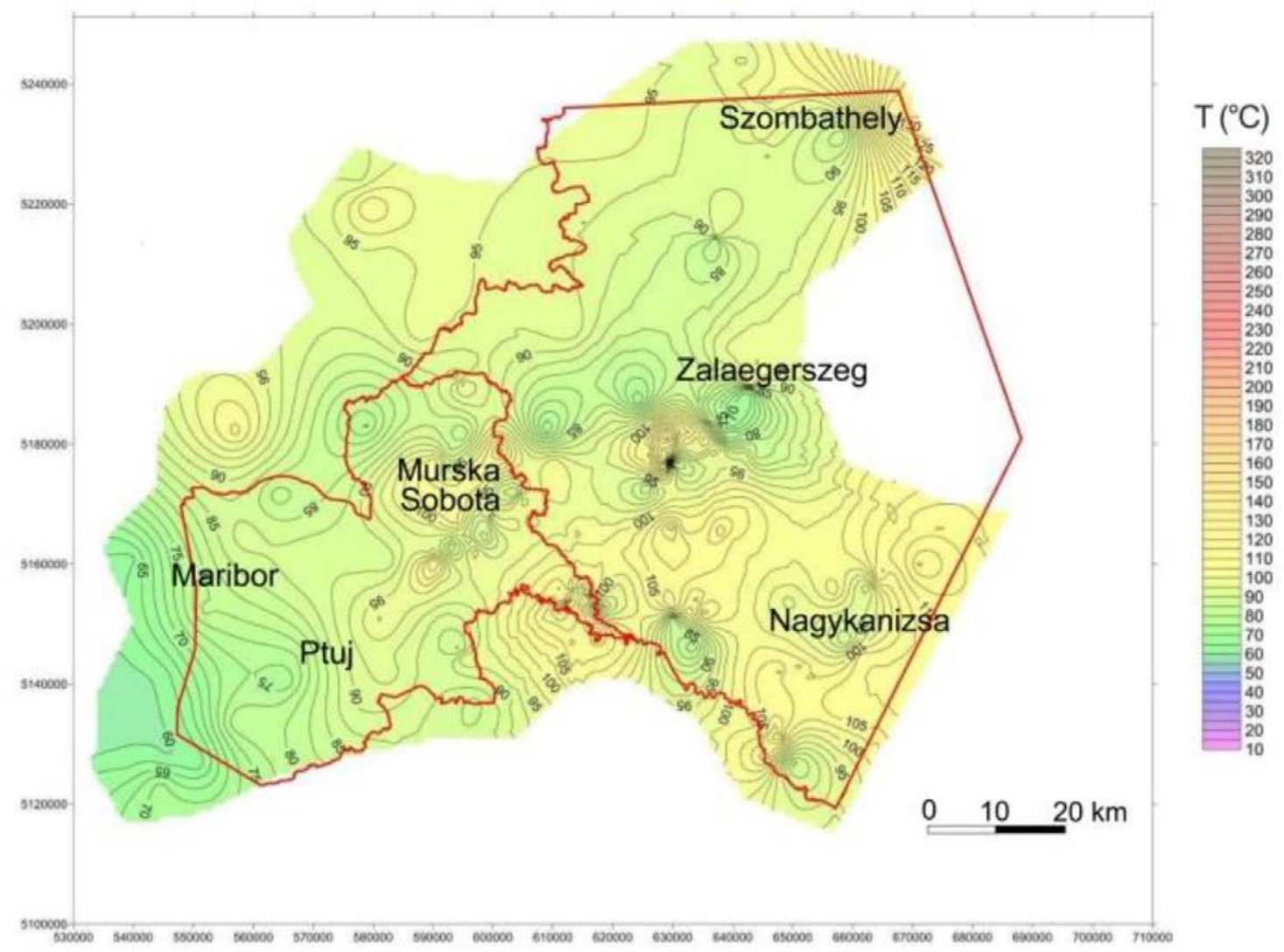

Figure 2: Temperatures at 2000 m depth.

the rock density changes too. Temperature increase in NE Slovenia can be described by the following equation:

$T_{N E}=\frac{576 \cdot H^{3.86}}{\left[1.09 \cdot\left(e^{-0.81 H}-1\right)+2.72 \cdot H\right]^{2.86}}+11.6$

Based on the geothermal gradient, the projections for the prospect of use of a single area for geothermal energy are made [8].

\section{Amount of geothermal water that can be produced at constant temperature}

Production time at constant temperature represents the relation between production reserves and well output or well yield:

$\tau_{c}=\frac{A \cdot h \cdot(c \rho)_{L}}{W_{p} \cdot(c \rho)_{w}}($ years $)$ where $W_{p c}=\Delta W \cdot \tau_{c}$. The total amount of the produced geothermal water is calculated as follows:

$W_{p c}=\frac{A \cdot h \cdot(c \rho)_{L}}{(c \rho)_{w}}\left(\right.$ in $\left.^{3}\right)$

$A=$ flow area of the deposit (in $\mathrm{m}^{2}$ );

$h=$ flow height of the deposit (in $\mathrm{m}$ );

$(c \rho)_{w}=$ volume-specific heat capacity of water (in J/m $/ \mathrm{m}^{3} \cdot \mathrm{K}$ );

$(c \rho)_{L}=$ volume-specific heat capacity of the deposit (in $\mathrm{J} / \mathrm{m}^{3} \cdot \mathrm{K}$ );

$W_{p c}=$ annual geothermal water production (in $\mathrm{m}^{3} /$ year);

$\tau_{c} \geq \frac{A \cdot h \cdot(c \rho)_{L}}{q_{W} \cdot(c \rho)_{w}}$

$q_{w}=$ projected production of geothermal water (in $\mathrm{m}^{3}$ /day). 


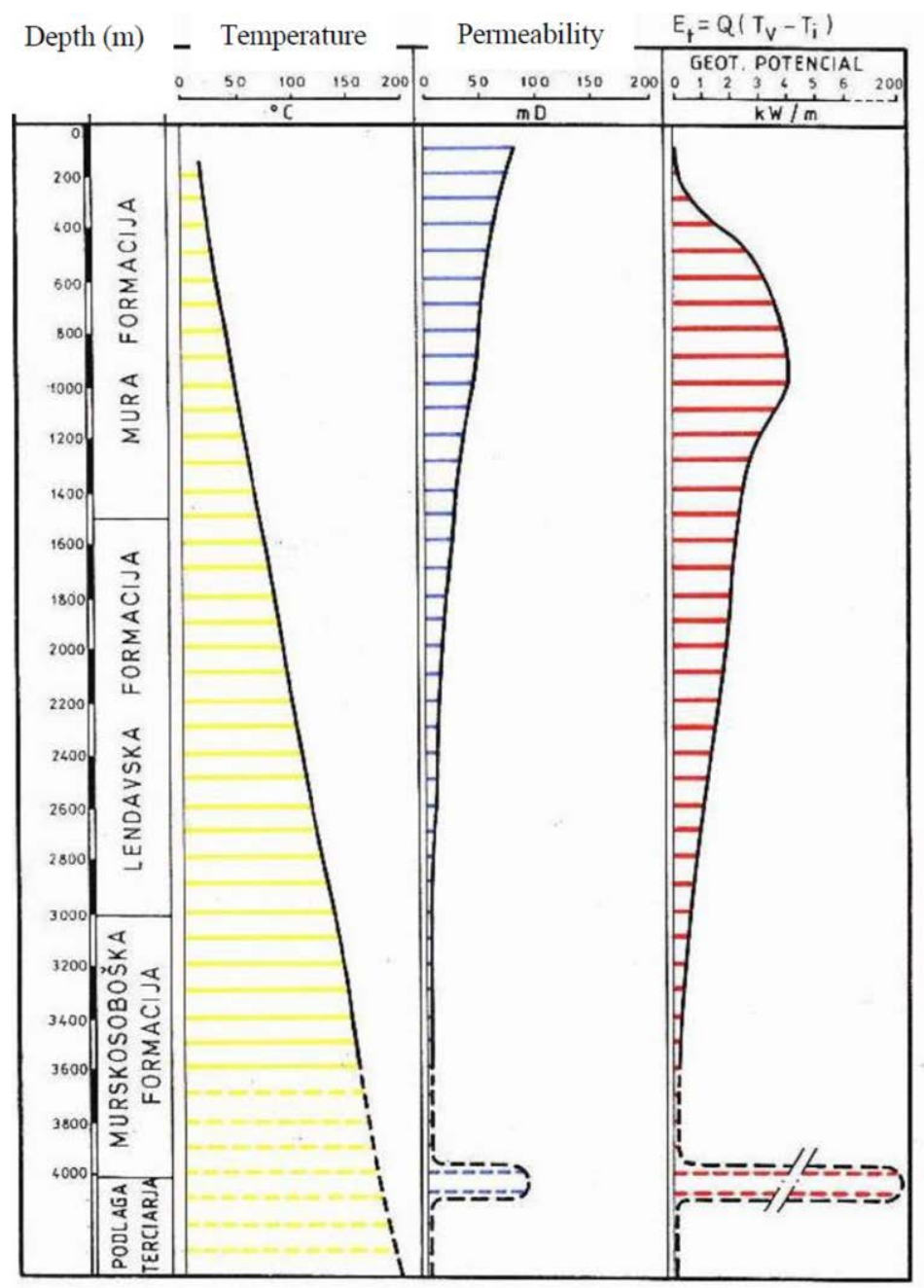

Figure 3: Interdependency of temperature and porosity in NE Slovenia.

\section{Results and discussion}

We are interested in how long the water will retain the constant temperature without any impact of the cold return water inflow (random data) [4-7]:

$V_{L}=$ flow volume of the deposit $\left(80000000 \mathrm{~m}^{3}\right)$; $q_{W}=$ projected extraction amount of geothermal water $\left(7000 \mathrm{~m}^{3} /\right.$ day $)$;

$\Phi=$ porosity of the productive strata (16\%);

$c_{m}=$ specific heat of the massif $882.2 \mathrm{~J} / \mathrm{kg} \cdot \mathrm{K}$, and density $2700 \mathrm{~kg} / \mathrm{m}^{3}$;

$c_{w}=$ specific heat of water, which is defined as follows:

specific heat of water, at hydrostatic pressure of water 247 bars and temperature $175^{\circ} \mathrm{C}$, equals $4271 \mathrm{~J} / \mathrm{kg} \cdot \mathrm{K}$, but as $\mathrm{CO}_{2}\left(26 \mathrm{~m}^{3} / \mathrm{m}^{3}\right)$ is present in the water, the value should be reduced for $\sim 5 \%$ and also equals $4058 \mathrm{~J} / \mathrm{kg} \cdot \mathrm{K}$.

$\rho_{w}=$ water density in the deposit $\left(923.6 \mathrm{~kg} / \mathrm{m}^{3}\right)$ Volume-specific heat capacity of water is derived as follows:

$(c \rho)_{w}=4058 \times 923.6=3.748 \times 10^{6} \mathrm{~J} / \mathrm{m}^{3} \mathrm{~K}$.

Volume-specific heat capacity of the deposit is derived as follows:

$(c \rho)_{L}=(c \rho)_{w} \cdot \Phi+(c \rho)_{m} \cdot(1-\Phi)=3.748 \times 10^{6} \times$ $0.16+882.2 \times 2700 \times(1-0.16)$;

$(\mathrm{c} \rho)_{L}=2.60 \times 10^{6} \mathrm{~J} / \mathrm{m}^{3} \mathrm{~K}$ 


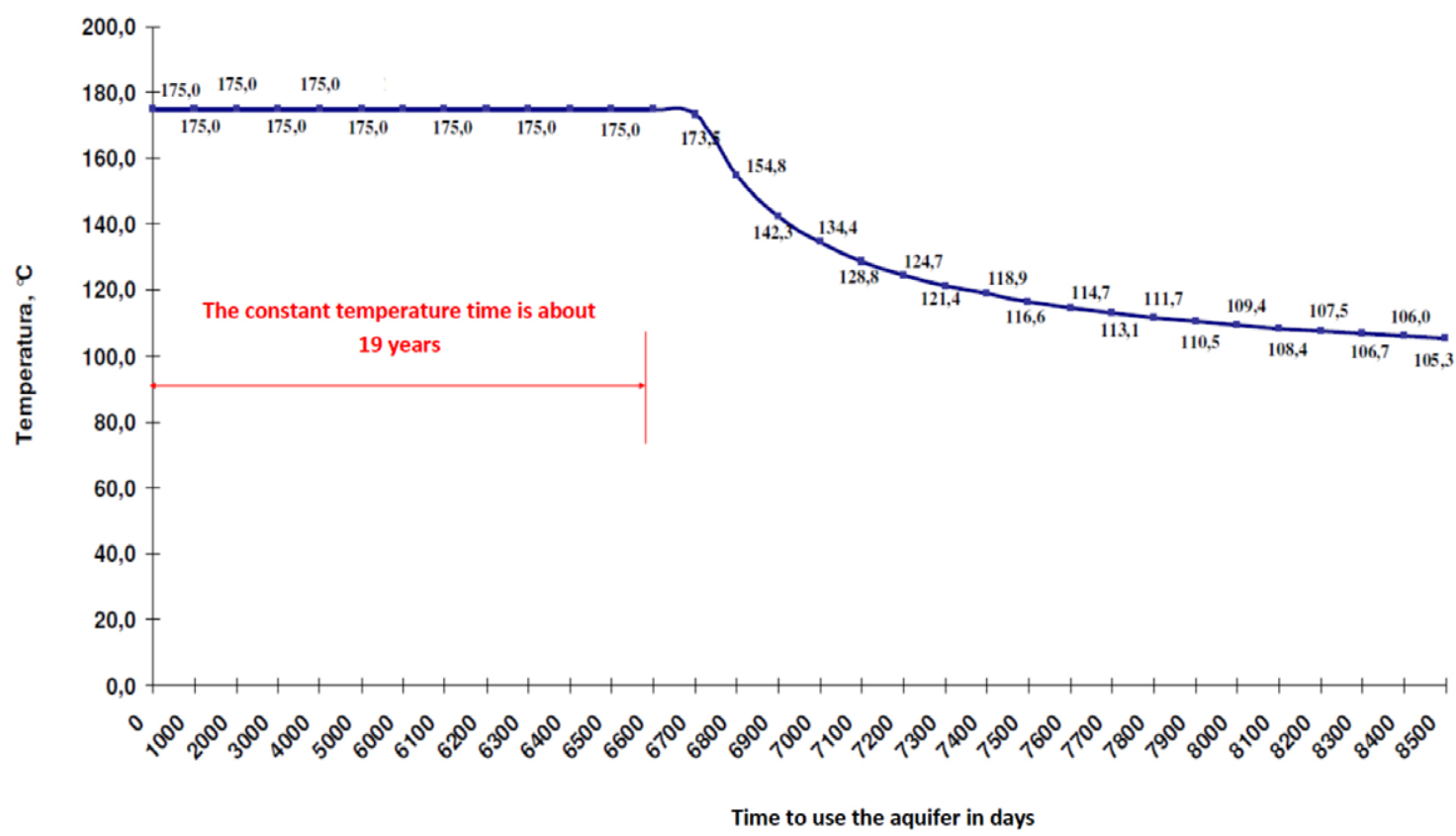

Figure 4: Aquifer exploitation time (in days).

Exploitation of the water with constant temperature from the deposit can last for the following duration:

$\tau_{c} \geq \frac{A \cdot h \cdot(c \rho)_{L}}{q_{W} \cdot(c \rho)_{w}}=\frac{68000000 \times 2.6 \times 10^{6}}{7000 \times 3.748 \times 10^{6}}=$ $=6739$ days $\approx 19$ years.

After the period of 19 years, the water temperature will start to decrease because of colder return water inflow from the reinjection well. This finding stands in case the geothermal water is exploited for production of electrical energy and the reinjection well is not sufficiently far away from the production well.

\section{Conclusions}

Geothermal energy belongs among renewable energy resources. Geothermal energy is widely used for the heating of residential and other buildings, as well as for electrical energy production. In NE Slovenia, we have the largest potential for exploitation of geothermal energy. Exploitation of geothermal ener- gy in NE Slovenia is already causing problems due to excessive production from geothermal aquifers. Water table drawdown is observed in aquifers, meaning that not enough used water is returned back into the aquifer. Calculations present information on the potential geothermal water reserves that are not affected by the cold return water inflow from reinjection wells after a certain period of production time. The calculations apply for continuous production of geothermal water from the aquifer without significant pumping breaks.

\section{References}

[1] DiPippo, R. (2012): Geothermal power plants: principles, applications, case studies, and environmental impact. Third Edition, Amsterdam: Elsevier, 624 p.

[2] Golub, M., Kurevija, T. Koščak Kolin, S. (2004): Thermodynamic Cycle Optimization in the Geothermal Energy Production. Rudarsko-Geološko-Naftni Zbornik, 16, pp. 65-69.

[3] Golub, M., Kurevija, T., Pravica, Z. (2006): Maximum Energy Output of Geopressured Geothermal Reservoirs in Croatia, International Congress Energy and 
Environment 2006, Opatija, Croatia, 25-27 October 2006, pp. 121-130.

[4] Kaluđerović, D., Vižintin, G. (2014): Modflow USG - the next step in mathematical modelling of underground water. RMZ - Materials and geoenvironment, 61(4), pp. 241-247.

[5] Vižintin, G., Vukelič, Ž., Vulić, M. (2008): Monitoring the geothermal potential of deep tertiary aquifers in north-east Slovenia using old abandoned oil and gas wells = monitoring geotermalnog potencijala dubokih tercijarnih vodonosnih horizonata u severnoistočnoj Sloveniji uz pomoč starih napuštenih bušotina nafte i gasa. In: Ristović, I. (ed.). Savremene tendencije u razvoju energetskog rudarstva $=$ Modern Tendencies in the Development of Energy Mining: zbornik radova = proceedings. Beograd: Rudarsko-geolološki fakultet, pp. 39-52.
[6] Vukelič, Ž., Vulić, M. (2014): Ocena in natančnost ocene 3D-položaja točk v vrtini = Evaluation of 3D positions and the positional accuracy of points within a borehole. Geodetski vestnik, 58(2), pp. 327-341.

[7] Vukelič, Ž., Kraljić, M., Dervarič, E. (2013): Lendava the first geothermal city in Slovenia. 5th Jubilee Balkan Mining Congress, Ohrid, Macedonia, 18th-21st September 2013. Skopje: Association of mining and geological engineers of Macedonia, pp. 1-12.

[8] Rman, N., Lapanje, A., Rajver, D. (2012): Analiza uporabe termalne vode $\mathrm{v}$ severovzhodni Sloveniji = Analysis of thermal water utilization in the northeastern Slovenia. Geologija, 55(2), pp. 225-242. 
